\title{
Chapter 2 \\ The Case for an Indigenous Knowledge Based Curriculum
}

The relevance of education is founded on the assumption that, at every point in time, it will be built around the human experiences of the learner. Distinct from training, which thrives on repetition without much emphasis on philosophical understanding, education should be motivated by the need to understand how and why things are. Education must, therefore, focus on helping the learner think clearly and without inhibition or undue dependence on abstract images. As much as possible, formal education should be a reflection of life itself, the function of education, then being to "direct, control and guide personal and social experiences" (Ozmon and Carver 1986, 114). As most human experiences are not certain or predetermined, education should assume an experimental direction, ready to engage in exploration and discovery of answers to emerging challenges that plague human existence. Nothing ought to be cast in stone as far as the human experience-which education embodies-is concerned. Education, in its entirety, should not be based on some perfected system of truth, but should strongly encompass a system of knowing that is rooted in experimentation, existing and emerging reality. Students should be exposed to as much as possible of the real world and not just to a fraction of it. Along that line, interdisciplinary approach to education is ideal since in reality life is not compartmentalized into different disciplines. The unfortunate result of the over-fragmentation in the form of disciplinarity, which has characterized formal education, is that undue attention is placed "upon subject matter rather than on the contents of the child's own experience" (Dewey 1916, 10).

Education ensures continuity of life in any society. As individuals in a society get old and die, a new generation is birthed that needs to be inculcated into the values, mores, culture, and the way of life of society. For Dewey, human beings "are born not only unaware of, but quite indifferent to, the aims and habits of the social group and have to be rendered cognizant of them and made to become actively interested; education and education alone, spans the gap" (Dewey 1916, 3). Education ensures continuity in society, and this is achieved through transmission of values, anchored on effective communication; "society not only continues to exist by transmission, by 
communication, but it may fairly be said to exist in transmission, in communication" (Dewey 1916, 3).

Education should assist individuals within a society to understand their lived reality. Individuals must learn from experiencing real life in order to develop freely and be able to contribute to the development of society. Memorization, abstract learning, drill and the "learning of fixed subject matter", therefore will not be very beneficial to the individual seeking to explore and understand the realities of his own lived experiences. As Dewey notes

The curriculum should be conceived, therefore, in terms of a succession of experiences and enterprises having a maximum of likeness for the learner with a view to giving the learner that development most helpful in meeting and controlling life situations... the method by which the learner works out these experiences, enterprises, and exercises, should be such as calls for maximal self-direction, assumption of responsibility, of exercise of choice in terms of life values (Dewey 1916, 13).

The role of the school should be to serve as a coordinating spot for all of the knowledge presented in the different education platforms, which the individual encounters in his everyday living. Education is life itself, and not a prerequisite to life.

Education can and should also act as a change agent in a society. Scholars have proposed that the chaos and crises being experienced by society today can only be addressed with education as a tool of social activism (Ozmon and Carver 1986, 144). Educators should engage society actively, for mere knowledge is useless if not backed by action. George S. Count, in his seminal work, Dare the Schools Build a New Social Order (New York: John Day, 1932), contends that educationists must take an active role in social transformation, in a radical approach that was new to the academia. Count opines that it is the job of educators to ensure that the curriculum is fashioned in such a way as to constantly question given assumptions of society and institute practical ways of enforcing change. For Count

\footnotetext{
Education ...must... face squarely and courageously every social issue, come to grips with life in all of its stark reality, establish an organic relation with the community, develop a realistic and comprehensive theory of welfare, fashion a compelling and challenging vision of human destiny, and become less frightened than it is today... (Counts 1932, 2).

For Counts,

That teachers should deliberately reach for power and make the most of their conquest is my firm conviction. To the extent that they are permitted to fashion curriculum and the procedures of the school, they will definitely and positively influence the social attitudes, ideals, and behavior of the coming generation. In doing this they should resort to neither subterfuge or false modesty... (Counts 1932, 3).
}

Education should assist its beneficiaries in setting goals. Since modern culture presents man with conflicting values and ideas, it is the job of the teacher or educator to "establish clear goals for survival" (Ozmon and Carver 1986, 139). The educator plays a crucial role in ensuring that individuals within society are not carried away by popular culture, by constantly displaying the picture of the "truth" in front of society. This truth is nothing new but is the historically subscribed to values, which society has lost as a result of the encroachment of modernization exemplified by science, technology, and industrialization. 


\section{Unintended Aims of Formal Education}

Also referred to as the hidden curriculum, there are certain outcomes that are not often intended, but which are inevitably part of what is placed within the individual subjected to the schooling process. This hidden curriculum includes the pedagogical structures and procedures, the messages which the teacher tacitly transmits to the students, which although not a part of the formal curriculum, are heavily influential in determining the learning outcome of the students. For Doug White, there is no curriculum educational program or policy that is "ideologically or politically chaste", as curriculum as a concept is inherently and directly linked to social, cultural, gender, power, and class issues. There is a need for exceptional vigilance, for the eyes of individuals to be enlightened to specific assumptions that code what is otherwise passed as proven knowledge. This affords the students the opportunity to develop a discourse free from distortions, enabling the learner to "appropriate the most progressive dimensions of their own cultural histories..." (Darder et al. 2003, 46). Education should, therefore, empower the learner to ask historical questions and examine assumptions and "accepted meanings and appearances" (McLaren in Darder et al. 2003, 62). Without an emphasis on such critical thinking in education, the school will serve more as an instrument for the perpetuation of the ideas of the dominant class. Education is then able to orientate students into society as liberated individuals who are able to understand the many sides to a problem that the society faces without necessarily being dogmatized to sing the elitist capitalist tunes.

Essentially, therefore, curriculum in the present-day academic context entails much more than study programs, classroom texts, or syllabi, but indeed represents the "introduction to a particular form of life;" serving in part "to prepare students for dominant or subordinate positions in the existing society" (Giroux and McLaren 1986, 228). The curriculum emphasizes some knowledge forms over others, thereby granting affirmation to a section of people above the rest. Educationists, therefore, must be critical about the constitution of textbooks, course materials, and curriculum content in relation to the social constitution of the learners. How does the curriculum affirm the knowledge forms, values, and ideals of a segment of the society while ignoring, de-emphasizing or even ridiculing that of another? The curriculum is able to achieve this in a way that seems unobtrusive and is never explicitly stated, through the "hidden curriculum" (McLaren, in Darder et al. 2003, 75).

No curriculum is devoid of partisanship or ideological persuasion, and "the concept of the curriculum is inextricably related to issues of social class, culture, gender and power" (McLaren, in Darder et al. 2003, 76). The school environment, instructional materials, styles, examples, teacher requirements, grading procedures, and every other thing involved in the academic environment transmits certain messages to the learners. These messages are filled with expectations which are geared towards a particular mindset, affirming one gender, race, culture, practice, system over the other. There is no universally neutral curriculum, and every attempt at forging one results in what Doug White would refer to as the "multinational curriculum." White asserts that 
The multinational curriculum is the curriculum of disembodied universals, of the mind as an information-processing machine, of concepts and skills without moral and social judgment, but with enormous manipulative power. That curriculum proposes the evaluation of abstract skills over particular content, of universal cognitive principles over the actual conditions of life" (Doug White, "After the Divided Curriculum," The Victorian Teacher 7 (1983, March).

The end goal for every educator should be to unearth or identify the "structural and political assumptions upon which the hidden curriculum rests and to attempt to change the institutional arrangements of the classroom so as to offset the most undemocratic and oppressive outcomes." (Mclaren, in Darder et al. 2003, 76).

\section{Colonialism and the Hidden Curriculum}

Colonialism and other forms of oppression are some of the surest ways of covertly structuring a curriculum to reflect and perpetuate the colonizing power's epistemology. Peter Pericles, in making a case for a redefinition of pedagogy in the United States amongst the nonwhite student population, contends that basic questions must be asked in order to arrive at the relevance of what is presented as universal education for certain segments of the American society. Questions like; "what are the value and place of nonwhite peoples in an Anglo-European nation and society? What should be the role of education for poor, indigenous, nonwhite children?" (Peter Pericles in Trifonas 2003). Responding to Pericles, Trifonas (2003) argues that the history of nonwhite America is found in capitalist oppression. Their subjugation has, from the beginning, served as a means to accumulate more wealth by the Anglo-European class. Whatever education made available to this class of people must be examined within this historical framework of internal colonialism and later neo-colonialism.

\footnotetext{
A basic premise of our call for a decolonizing pedagogy is that the dominant economic, cultural, political, judicial, and educational arrangements in contemporary American society are those of an internal neo-colonialism produced by the mutually reinforcing systems of colonial and capitalist domination and exploitation that have organized social relations throughout history of what today constitutes the United States (Trifonas 2003, 13).
}

Trifonas defines colonialism in the United States as the era of legalized domination by the Anglo-European race during the seventeenth, eighteenth, and nineteenth centuries. The abrogation of these institutionalized colonial structures through such "landmark legislations" as the Emancipation Proclamation, the Civil Rights Act, Brown versus Board of Education, the Indian Self-Determination and Education Assistance Act, and others heralded the era of neo-colonialism (Trifonas 2003, 16). Although slightly altered in terms of appearance, Trifonas insists that the core of oppression and domination has been retained, and manifests itself through several institutions, one of them being education. He contends that the continued maintenance of the exploitative features that characterized America's social past, in many more ways than one, is responsible for the present social reality of the country, stating 
that "several years after the formal end of internal colonialism, The United States remains sharply divided along the very same lines that characterized the nature of the colonial system" (Trifonas 2003, 16).

Trifonas (2003) believes, however, that the existence of colonialism at some point in the history of the United States, with the nonwhite population at the receiving end, does not call for a requiem to the social advancement of that group of people. Quoting Marx and Engels, he opines that "human existence and society are produced by people and can be transformed by people." (Trifonas 2003, 16). Through praxis which is the process of "guided action aimed at transforming individuals and their world," it is possible to reverse the existing social reality of the formerly colonized people. Praxis is made possible by teaching the formerly colonized people the process of critical thinking or a "critical consciousness of social existence" (Trifonas 2003, 19). The education of formerly colonized people cannot be the same as it was during the era of colonization, in order to transform their world from that of mental dependence on the colonizer to liberation and independence.

Trifonas argues that, to ensure real independence through the right kind of education, classroom content must integrate "particular curriculum content and design, instructional strategies and techniques, and forms of evaluation" (Trifonas 2003, 20). This is necessary, as colonialism is entrenched in the mental process of the colonized through the "curricula content and design, the instructional practices, the social organization of learning, and the forms of evaluation that inexorably sort and label students into enduring categories of success and failure of schooling" (Trifonas 2003, 21). Specifically, Trifonas calls for the liberating pedagogy to pay detailed attention to history as a social tool to examine the present (Trifonas 2003, 33). Given theories and assumed conceptual frameworks should constantly be reexamined by teachers and students, with a view towards ridding them of hidden neo-colonial underpinnings. This attempt at curriculum review is a continuous process, and is relative to the environment. In essence, the content of a decolonizing pedagogy in Nigeria might differ remarkably from that of India, but the bottom line is that both are open to a process of modification and expansion, according to environmental dictates.

The call for a reassessment of the curriculum does not indicate a repudiation of the "traditional curriculum necessary for academic success within the present system of schooling" (Trifonas 2003, 34). There is the recognized need for students to be exposed to a form of universal curriculum, which when mastered ensures academic success through an understanding of the environment, society, and ensuring creativity and innovation. The decolonizing pedagogy will encompass all of that, and much more, by giving the learners a sense of self-awareness, which the supposedly "universal curriculum" lacks (Trifonas 2003, 35).

In Pedagogy of the Oppressed (Seabury Press: New York, 1968), Paulo Freire argues that the major aim of education should be to achieve critical consciousness, for both teachers and learners to be able to question assumed realities, for "teachers and students co-intent on reality, are both subjects not only in the task of unveiling that reality and coming to know it critically, but in the task of re-creating that knowledge" (Freire 1968, 56). Knowledge is achieved through continuous invention and 
reinvention, through constant inquiry into the nature of "reality." Richard Shaull in the introduction to Freire's text notes that;

There is no such thing as a neutral educational process. Education either functions as an instrument which is used to facilitate the integration of the younger generation into the logic of the present system and bring about conformity to it, or it becomes "the practice of freedom," the means by which men and women deal critically and creatively with reality and discover how to participate in the transformation of their world (Freire 1968, 15).

Freire, in a term he referred to as the "banking concept of education" argues that "education has been used for the maintenance of the oppressive status quo; knowledge is a gift bestowed by those who consider themselves knowledgeable upon those whom they consider to know nothing. Projecting an absolute ignorance onto others, a characteristic of the ideology of oppression, negates education and knowledge as processes of inquiry" (Freire 1968, 58). Freire notes that "authentic education is not carried on by "A" for " $B$ " or by "A" about " $B$," but rather " $A$ " with "B," mediated by the world-a world which impresses and challenges both parties, giving rise to views or opinion about it" (Freire 1968, 82). The education system that exalts abstraction, cognition and intellectualism above an inquiry into reality turns the learners into mere recipients-passive individuals who sit to receive from those who already have knowledge of the truth. The educated man in this context becomes the man who has adapted to the world as is explained to him. To Freire, this sort of education "is well suited to the purposes of the oppressors, whose tranquility rests on how well men fit the world the oppressors have created, and how little they question it" (Freire 1968, 63).

Freire argues that the present form of education obtainable across formerly colonized territories is anti-creativity, as it "attempts to maintain the submersion of consciousness". Ideal education, however, should strive towards "the emergence of consciousness and critical intervention in reality" (Freire 1968, 68). In order to foster the freedom to be innovative and herald development, education must cease to be presented as abstract, universal, and independent of the learner's surroundings and existing realities. For Freire, it is crucial that education or curriculum represent "situations familiar to the individuals whose thematic are being examined, so that they can easily recognize the situation (and thus their own relation to them)... it is inadmissible to present pictures unfamiliar to the participant" (Freire 1968, 107). The most important part of education, therefore, is the ability to make learners feel like masters of their own thinking by enabling them the freedom to analyze their own world experience and not that of another.

India's post-independence reconstruction of its educational curriculum was rooted in an understanding of the effects of colonialism on the education system of the country. In Towards New Education (Ahmedabad: Navajin Press 1956), Mahatma K. Gandhi, father of India's independence reflects on the imposition of Western ideals and values over India in the education offered by the British in the colonial era. Gandhi condemns British education policy in India, which unlike the indigenous Indian education, emphasized mechanical learning instead of character development; "we become lawyers, doctors and school masters not to serve our countrymen, but to bring 
us money" (Gandhi 1956, 22). Colonial education focuses on producing people for British styled living and does not encourage the building of an authentic progressive Indian society. Citing the example of Baroda, a predominantly agrarian society where although British education (mainly reading and writing at the elementary level) has been taught to its inhabitants for over 50 years, there has not been any noticeable improvement in the productivity and standard of living of the farmers,

The sanitation of their villages is as primitive as in the other parts of India. They do not even know the value of manufacturing their own cloth. Baroda possesses some of the richest lands in India. It should not have to export its raw cotton. It can easily become a self-contained State with a prosperous peasantry. But it is bedecked in foreign cloth - a visible sign of their poverty and degradation... The fact is the education in Baroda is an almost slavish imitation of the British type. Higher education makes us foreigners in our own country... There is no originality or naturalness about it. It need not be at all original if it would only be ab-original (Gandhi 1956, 5).

Mahatma Gandhi rejects the nationwide curricula that emphasized such "universal" subjects such as physics, chemistry, and mathematics and completely ignored India's greatest industry of "spinning and weaving" (Gandhi 1956, 23). While not making a case for India's education to be turned to mere spinning and weaving institutes, he insists that such indigenous knowledge and industry must be combined with the universal courses in order to produce creative, innovative and well-grounded citizens who are in touch with their environment and the wider society.

Speaking of what is termed national education in India, Mahatma Gandhi asserts that "the curriculum and pedagogic ideas which form the fabric of modern education were imported from Oxford and Cambridge, Edinburgh and London. But they are essentially foreign, and till they are repudiated, there never can be national education" (Gandhi 1956, 26). Gandhi rejects the British entrenched education, which upturned the ancient educational system in India founded on the tradition of pride and service. Education to be considered sound must be able to ensure continuity from one generation to another. No generation should, due to education, lose touch of the investments, knowledge bank, and core values of its predecessors. British education, Gandhi contends, has succeeded in doing this by breaking the continuity of India's existence.

The system must be scrapped; enquiry must be made promptly as to what constituted the elements of education before Indian Universities were constituted, before Lord Macaulay wrote his fatal minutes. Promptness is essential, because the race of old teachers is nearly extinct and the secret of their methods may die with them. The resuscitation of those curricula may mean the disappearance of political history and geography... we dare aver that they strike us as infinitely more efficient and satisfactory than the latest thing to come out of Europe" (Gandhi 1956, 28).

Gandhi decried the unrelated nature of the textbooks that the students were using to their own real-life experiences. The colonial curriculum did not imbibe any sense of pride in the student's history and surroundings, such that the more he studies, the farther removed he is from his identity until "he becomes estranged from his surroundings" and "he feels no poetry about the home life, the village scene are all a sealed book to him, his own civilization is presented to him as imbecile, barbarous, 
superstitious and useless for all practical purposes. His education is calculated to wean him from his traditional culture" (Gandhi 1956, 29).

Mahatma Gandhi avers that mass or universal education is not suitable for the Indian child. For the most part, it is comprised of unnecessary information that ends up crushing all originality, creativity, and innovation in the learner, turning them into automated machines, designed to regurgitate canonical knowledge, abstracted from their everyday realities.

Gandhi blames the foreign medium of expression utilized in India's education system. According to him, English language as a medium of expression has stifled spontaneity, the precursor of creativity, in the Indian classrooms. The students have become adept at memorization, become imitators and gone very far from being creators. Indian children have been turned into foreigners in their own land, as the students spend years trying to master the foreign language instead of investing those years in developing their intellectual capacity (Gandhi 1956, 48). Gandhi relates a personal story of being punished in class for speaking Gujarati, his mother tongue, and spending four years in the classroom learning Arithmetic, Geometry, Algebra, Chemistry and Astronomy in the English language, instead of the one year it should have taken him to learn those same subjects in Gujarati.

In True Education, (Ahmedabad 1962), Gandhi compares the Dutch medium of instruction, which the black of South Africa are educated in, and the English which the Indians are educated in. In both cases he submits that the resultant effect is the same; students from both societies graduate to become mere imitators of their foreign masters, highly constrained from churning out original ideas, although they may be as well educated, if not more, than their English counterparts. He contrasts this with the situation in Japan where the use of mother tongue as the medium of instruction in the schools has brought about an awakening in the people, leading to originality and huge strides in science and technology education (Gandhi 1962, 13).

Gandhi regrets the lack of attention paid to indigenous knowledge in the assembling of the curriculum of learning in Indian institutions. Instead, the British disparaged Indian literature, dismissing it as being overtly superstitious in nature, and its civilization as demonic. He accuses the colonialists of being more interested in producing lawyers, doctors, and clerks who would help the ruling English officers in discharging their duties to the Queen of England. In the teaching of History and Geography, Gandhi recollects being made to memorize "the counties of England" and was taught nothing about India or the continent of Asia. In History, he was taught the English history of India, starting with the arrival of the first Englishmen in the country and the subsequent colonial triumph. Both subjects, he loathed extensively, for the abstract nature of the former and for the demeaning of India in the latter. In Arithmetic, the ancient Indian methods of calculations still in use outside of the classroom were ridiculed, while the English way of calculation was forced upon the students (Gandhi 1962, 28). In Science, the outdoor nature of learning such subjects as astronomy was not emphasized, although the Indian weather was nothing like the English weather which often constrained students to stay indoors. In Health Sciences, indigenous Indian medical remedies were disparaged by the colonial education curriculum, although no immediate alternative was available. People died in 
record numbers without the advantage of the remedies which their forefathers utilized in times of ill health. In Physical education, rather than encourage the study and the training in the inexpensive but highly entertaining indigenous games such as "gend-balla, gilli-danda, kho-kho, sat-tali, kabaddi", etc., Indians have been taught to idolize tennis, cricket, and football, sports very expensive to engage in and which the Indian physical education teachers lacked appropriate understanding of the rules of the game (Gandhi 1962, 30). Another debilitating factor is the subjects that are not being taught at all in the schools, such as agriculture. Although $85-90 \%$ of Indians were engaged in agriculture, the system of education did not encourage this very important field of learning. Agriculture had no place in the colonial school syllabus in both primary and post primary education. The same can be said of the weaving industry which is conspicuously omitted from the curriculum. Music is another area very important in the culture and life of Indians, which was not given any form of recognition in the colonial Indian system of education (Gandhi 1962, 32).

\section{References}

Count G (1932) Dare the schools build a new social order. John Day, New York

Darder A, Baltodano M, Torres R (eds) (2003) The critical pedagogy reader. Routledge, New York Dewey J (1916) Democracy and education. Free Press, New York

Dewey J (1959) Moral principles and education. Philosophical Library, New York

Freire P (1968) Pedagogy of the oppressed. Penguin Books, Harmondsworth

Gandhi MK (1956) Towards new education. Navajin Press, Ahmedabad

Gandhi MK (1962) True education. Navajivan Publishers, Ahmedabad

Giroux H, Purpei D (1983) The hidden curriculum and moral education: deception or discovery?. McCutchen Publishing Corp, Berkeley

Giroux H, McLaren P (1986) Harv Educ Rev 56(3):232-233

Ozmon H, Craver S (1986) Philosophical foundations of education. Pearson, London

McLaren P (2003) Critical pedagogy: a look at the major concepts. In: Darder A, Baltodano M, Torres R (eds) The critical pedagogy reader. Routledge, New York

Trifonas P (2003) Toward a decolonizing pedagogy: social justice reconsidered. In: Trifonas P (ed) Pedagogies of difference: rethinking education for social change. Routledge, London White D (1983, March) After the divided curriculum. Vic Teach 7 
Open Access This chapter is licensed under the terms of the Creative Commons Attribution 4.0 International License (http://creativecommons.org/licenses/by/4.0/), which permits use, sharing, adaptation, distribution and reproduction in any medium or format, as long as you give appropriate credit to the original author(s) and the source, provide a link to the Creative Commons license and indicate if changes were made.

The images or other third party material in this chapter are included in the chapter's Creative Commons license, unless indicated otherwise in a credit line to the material. If material is not included in the chapter's Creative Commons license and your intended use is not permitted by statutory regulation or exceeds the permitted use, you will need to obtain permission directly from the copyright holder.

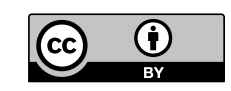

